important part in their pharmacological effects receives additional support from the incidence of low fibrinolytic activity in patients with rheumatoid arthritis and other inflammatory conditions.

\section{Summary}

A pilot study of blood fibrinolytic activity in rheumatoid arthritis led to the investigation of the effect of corticosteroid therapy on fibrinolysis.

In 17 in-patients the dilute blood-clot lysis-time, plasma fibrinogen level, and blood sedimentation rate were studied in the fasting, resting state before treatment and during treatment with corticosteroids. An increase of blood fibrinolytic activity occurred in 11 of 12 patients with inflammatory conditions and in all of 5 patients with non inflammatory conditions during treatment.

The results indicate that enhancement of fibrinolysis is a specific effect of corticosteroids, and not a consequence of improvement of inflammation.
The bearing of this finding on the therapeutic action of corticosteroids is discussed; and it is suggested that the time has come to consider fibrinolysis as a system of the body whose functions extend beyond the cardiovascular system to the tissues.

We thank Dr. R. F. Jarrett for allowing us to study two of the patients with ulcerative colitis, and Mr. John Evans for technical assistance. This study was supported by a grant from the SouthWestern Regional Hospital Board, for whose continuing support we are most grateful.

\section{REFERENCES}

Astrup, T. (1959). In Connective Tissues, Thrombosis, and Atherosclerosis, edited by I. H. Page, p. 223. Academic Press, New York and London.

Fearnley, G. R. (1951a). Proceedings of the Second A.C.T.H. Conference, New York, 11, 561 . (1951b). Lancet, 2, 501.

Balmforth, G., and Fearnley, E. (1957). Clin. Sci., 16, 645. and Bunim, J. J. (1951). Lancet, 2, 1113. and Chakrabarti, R. (1962). Ibid., 2,128 and Avis, P. R. D. (1963). Brit. med. 7., 1, 921.

and Vincent, C. T. (1960). Lancet, 2, 622

C. McFadzean, A. J. S., and Cook, J. (1956). Ibid., 1, 132

von Kaulla, K. N. (1963). Chemistry of Thrombolysis : Human Fibrino lytic Enzymes, p. 168. Thomas, Springfield, IIl., U.S.A.

\title{
Parainfluenza Infections in the Community
}

\author{
J. E. BANATVALA,* M.B., B.CHIR., D.C.H., D.P.H. ; T. B. ANDERSON, $†$ M.D. \\ B. B. REISS, $†$ M.B., B.S., M.R.C.P.
}

Brit. med.F., 1964, 1, 537-530

Since the isolation of a parainfluenza virus (Chanock, 1956) numerous investigators have demonstrated that these agents have a role in the aetiology of human respiratory infection. However, most surveys have involved select and conveniently accessible groups, such as children in hospital or residential institutions, students, or military personnel. The results of these surveys may not directly apply to members of the community living in their own homes.

We have studied the role of viruses in acute respiratory infection from September 1962 to August 1963 in the patients of two general practices in Cambridge. The complete findings will be published elsewhere, but the present paper describes our experience with respiratory infections by parainfluenza viruses. Most infection was associated with parainfluenza 1 virus, ${ }^{1}$ but a few cases of infection with parainfluenza 2 and 3 viruses also occurred.

\section{Study Population}

The material studied consisted of the patients of two general practitioners (T.B.A. and B.B.R.) working in different parts of Cambridge. The combined total was 5,178 patients and provided a cross-section of the permanent community of Cambridge-that is, the population apart from students. Patients

* Polio Research Fund Fellow, Department of Pathology, Tennis Court Road, Cambridge.

+ General Practitioner, Cambridge.

The parainfluenza viruses were originally named haemadsorption (H.A.) virus 1, croup-associated (C.A.) virus, and haemadsorption (H.A.) virus 2 , as tissue culture infected with these viruses adsorbed erythrocytes on to the cell surface. Later these viruses were renamed (Andrewes et al., 1959) myxovirus parainfluenza 1 (H.A.2), myxovirus parainfluenza 2 (C.A.), and myxovirus parainfluenza 3 (H.A.1). Sendai virus is closely related to, and represents a subtype of, parainfluenza 1 virus, although evidence of its isolation from human infection is equivocal. with acute febrile respiratory illness who were seen within 72 hours of onset were immediately referred for laboratory investigation by the general practitioner.

\section{Methods}

Collection of Specimens.-On notification of a case, one of us (J.E. B.) would visit the patient at home and obtain specimens for virological investigation. A pharyngeal swab was taken and immersed in 4-5 ml. of medium 199 containing 500 units of penicillin per ml., $500 \mu \mathrm{g}$. of streptomycin per ml., and $8 \mu \mathrm{g}$. of amphotericin B per ml. It was transported to the laboratory on crushed ice. Blood $(10 \mathrm{ml}$.) was taken at the same time from adult patients. Two to three weeks later more blood was taken and additional information about the course of the illness and the subsequent spread of the infection within the family was obtained. Occasionally specimens were collected from secondary cases in the same family, although their illnesses were not severe enough to require medical attention.

Tissue Culture.-Pharyngeal swab fluid $(0.2 \mathrm{ml}$.) was inoculated into secondary rhesus-monkey-kidney cultures within two hours of collection, the cultures having been thoroughly washed to remove all traces of calf serum. The monolayers were grown in 199 medium containing $5 \%$ calf serum, 100 units of penicillin per ml., $100 \mu \mathrm{g}$. of streptomycin per ml., $1.6 \mu$ g. of amphotericin B per ml., and $0.02 \%$ S.V.5 antiserum. Maintenance medium was similar to growth medium except that calf serum was not added. The cultures were incubated at $35^{\circ}$ C. in stationary racks, $20 \%$ of cultures being kept as uninoculated controls.

Identification of Viruses.-Cultures were tested for haemadsorption on the third, fifth, tenth, and subsequent days of incubation (Vogel and Shelokov, 1957). Fluid from cul- 
tures showing haemadsorption was passed into fresh cultures and later identified by haemadsorption inhibition, using rabbit antisera to parainfluenza 1,2 , and 3 viruses.

Serology.-Complement-fixation tests (C.F.T.) were carried out using "perspex" plates employing overnight fixation at $4^{\circ}$ C. as described by Bradstreet and Taylor (1962). Haemagglutination inhibition (H.I.) tests were carried out as described by Heath et al. (1962).

\section{Results}

Table I summarizes the principal laboratory findings of parainfluenza infection. There was evidence of parainfluenza infection in 35 patients. Blood was not taken from children; hence evidence of infection is by virus isolation alone ( 21 isolations). In adults there was serological evidence of infection in 14 patients, isolations being made in three of these cases.

TABLE 1.-Summary of Laboratory Findings in Cases of Parainfluenza

\begin{tabular}{|c|c|c|c|c|c|}
\hline Agent Responsible & & $\begin{array}{l}\text { Isolations } \\
\text { in Children * }\end{array}$ & $\begin{array}{c}\text { Serology } \\
\text { in Adults }\end{array}$ & $\begin{array}{l}\text { Isolations } \\
\text { in Adults }\end{array}$ & Total \\
\hline $\begin{array}{l}\text { Parainfluenza } 1 \\
\text { Parainfluenza } 2 \\
\text { Parainfluenza } 3\end{array}$ & $\begin{array}{l}\ldots \\
\cdots\end{array}$ & $\begin{array}{r}17 \\
2 \\
2 \\
\end{array}$ & $\begin{array}{c}10 \dagger \\
0 \\
4\end{array}$ & $\begin{array}{l}3 \\
0 \\
0\end{array}$ & $\begin{array}{r}27 \\
2 \\
6 \\
\end{array}$ \\
\hline Total $\quad .$. & $\ldots$ & 21 & 14 & 3 & 35 \\
\hline
\end{tabular}

* Serology not carried out in children.

$\dagger$ Includes three secondary cases in adults.

Age Distribution.-Table II shows the age distribution of cases occurring in the study population. Children were mainly affected, the younger age-groups having the highest incidence rates.

TABle II.-Attack Rates by Age for Parainfluenza Viruses

\begin{tabular}{|c|c|c|}
\hline Age in Years & No. at Risk & Attack Rate per 1,000 \\
\hline $\begin{array}{c}0-4 \\
5-14 \\
15-39 \\
40+\end{array}$ & $\begin{array}{r}322 \\
687 \\
1,849 \\
2,320\end{array}$ & $\begin{array}{r}43 \cdot 2 \\
12 \cdot 0 \\
2 \cdot 7 \\
3 \cdot 7\end{array}$ \\
\hline es ... & 5,178 & 6.6 \\
\hline
\end{tabular}

Clinical Findings.-Table III shows the principal clinical findings in children. The larynx was constantly involved in these infections. The infection varied in severity. Older children characteristically had a harsh spasmodic cough and a hoarse voice (croup). Infants and young children had more severe croup, often with evidence of laryngeal obstruction (acute laryngo-tracheo-bronchitis). Stridor was present in $6(43 \%)$ of 14 children in age-group 0-4 years. Some of the differences in symptomatology between the different age-groups in children were due to the fact that the younger children could not state their symptoms-for example, sore throat, headache. However, most of the differences are likely to be real-for example,

TABLE III.-Clinical Features of Illness in Virologically Confirmed Cases

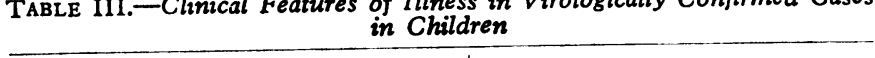

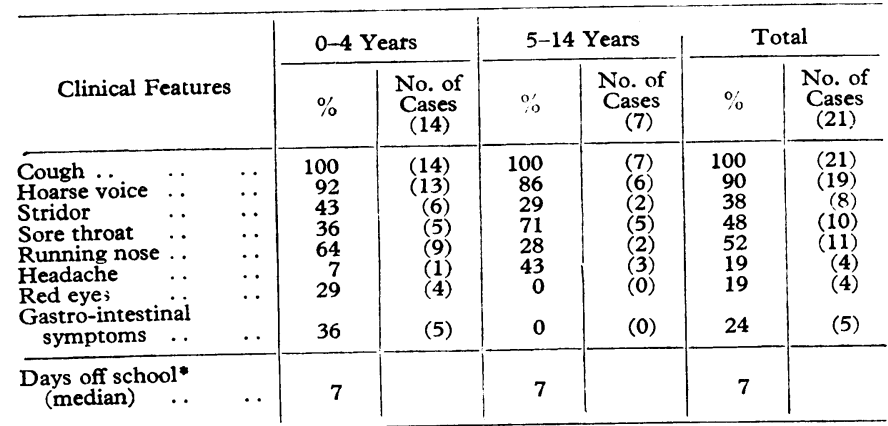

* In pre-school children this is taken as interval between onset and resumption of normal activity. presence or absence of gastro-intestinal symptoms. Adults presented a different picture. Cases secondary to infection in children usually had a mild illness. However, there were 11 instances of infection in adults in whom the clinical findings were suggestive of influenza (Table IV). The cough in adults was never croupy as in children, but the voice was frequently hoarse. Five of the 11 adults complained of lassitude and depression during convalescence, a phenomenon often observed in true influenza. The median time elapsing after the onset before these patients returned to work or resumed their normal household duties was nine days.

TABLE IV.-Clinical Features in 11 Virologically Confirmed Adult Cases

\begin{tabular}{|c|c|c|c|c|c|c|c|c|c|c|c|c|c|}
\hline $\begin{array}{l}\text { Clinical } \\
\text { Features }\end{array}$ & & 1 & 2 & 3 & 4 & 5 & 6 & 7 & 8 & 9 & 10 & 11 & Total \\
\hline $\begin{array}{l}\text { Cough } \\
\text { Hoarse voice } \\
\text { Sore throat } \\
\text { Headache } \\
\text { Running nose } \\
\text { Depression } \\
\text { Limb pains } \\
\text { Shivering } \\
\text { G.I. symptoms } \\
\text { Red eyes } \\
\text { Bronchitis }\end{array}$ & $\begin{array}{l}\ldots \\
\ldots \\
\ldots \\
\ldots \\
\ldots \\
\ldots \\
\ldots \\
\ldots \\
. .\end{array}$ & $\begin{array}{l}+ \\
+\end{array}$ & $\begin{array}{l}+ \\
+ \\
+ \\
+ \\
+\end{array}$ & $\begin{array}{l}+ \\
+ \\
+ \\
+ \\
+ \\
+\end{array}$ & + & $\stackrel{+}{+}$ & $\begin{array}{l}+ \\
+ \\
+ \\
+ \\
+ \\
+\end{array}$ & $\begin{array}{l}+ \\
+ \\
+ \\
+ \\
+ \\
+\end{array}$ & $\begin{array}{l}+ \\
+ \\
+ \\
+ \\
+ \\
+ \\
+ \\
+\end{array}$ & $\begin{array}{l}+ \\
+ \\
+ \\
+ \\
+\end{array}$ & $\begin{array}{l}+ \\
+ \\
+ \\
+ \\
+\end{array}$ & $\begin{array}{l}+ \\
+ \\
+ \\
+ \\
+ \\
+ \\
+\end{array}$ & $\begin{array}{r}10 \\
8 \\
8 \\
8 \\
7 \\
5 \\
4 \\
4 \\
3 \\
2 \\
2\end{array}$ \\
\hline
\end{tabular}

Seasonal Incidence.-The seasonal distribution is seen in Fig. 1. During the year under investigation, parainfluenza viruses were responsible for $18 \%$ of respiratory infections in 192 patients investigated. However, during the five months ending 31 January 1963, when parainfluenza viruses were prevalent in Cambridge, these viruses were responsible for $40 \%$ of all illness investigated in the laboratory. During this time $13 \%$ of infections could be attributed to other agents, these being Eaton agent (five cases), respiratory syncytial virus (three cases), adenoviruses (three cases). Apart from two cases in July, no further parainfluenza infection occurred after the end of January, influenza viruses being responsible for much of the infection in the following months.

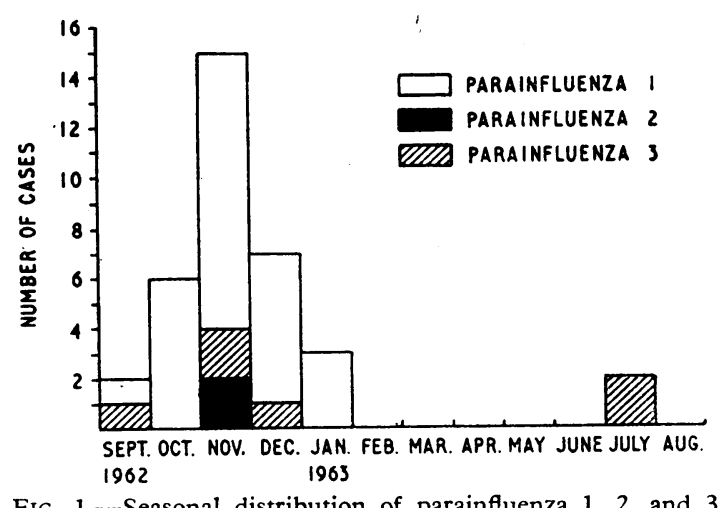
infection.

Secondary Attack Rate.-Table V shows the age-specific secondary attack rate calculated for 17 families in which there were four or more persons. The secondary attack rate-that is, the attack rate among the remainder of the family after excluding the index case(s) - was calculated as it was hoped to discover whether there was any relation between age and susceptibility under conditions of home exposure. Secondary cases were

TABLE V.-Secondary Attack Rate in 17 Families With Four or More Persons

\begin{tabular}{|c|c|c|c|c|c|c|c|}
\hline \multirow{2}{*}{\multicolumn{5}{|c|}{ Age in Years }} & \multirow{3}{*}{$\begin{array}{c}\begin{array}{c}\text { Persons } \\
\text { Exposed }\end{array} \\
10 \\
13 \\
41\end{array}$} & \multicolumn{2}{|c|}{ Attacked } \\
\hline & & & & & & \multirow{2}{*}{$\begin{array}{c}\text { No. } \\
8 \\
6 \\
9\end{array}$} & \multirow{2}{*}{$\begin{array}{l}\% \\
80 \\
46 \\
22\end{array}$} \\
\hline $\begin{array}{l}0-4 \ldots \\
5-14 \\
\text { Adults }\end{array}$ & $\begin{array}{l}\ldots \\
\cdots\end{array}$ & $\begin{array}{l}\cdots \\
\therefore\end{array}$ & $\begin{array}{l}\ldots \\
\cdots\end{array}$ & $\begin{array}{l}\cdots \\
\cdots\end{array}$ & & & \\
\hline All ages & . & . & $\cdots$ & $\cdots$ & $\begin{array}{l}64 \\
1\end{array}$ & 23 & 36 \\
\hline
\end{tabular}


taken as those presenting with acute respiratory illness within 10 days of the index case(s). Evidence of secondary infection was mostly clinical, specimens being taken on only three occasions (all confirmatory). The highest secondary attack rate occurred in the youngest age-group (0-4). Since this group presented with the more severe clinical manifestations it was particularly at risk.

Serial Intervals.-The serial interval is taken as the time in days elapsing between the index and secondary case(s) in a family episode. The distribution of serial intervals is seen in Fig. 2, the mean serial interval being 5.2 days (S.D. 2.2). This contrasts with the serial interval found in influenza, which is usually in the order of 2 days (Woodall et al., 1958).

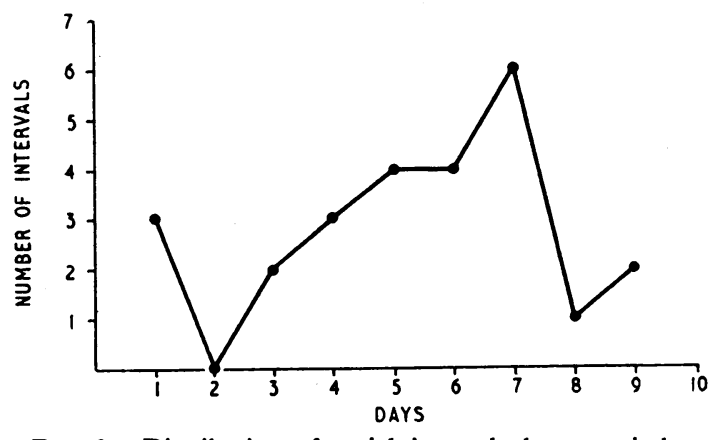

FIG. 2.-Distribution of serial intervals between index and secondary cases in parainfluenza infection.

Virus Isolation.-The time taken for detection of the parainfluenza viruses by haemadsorption is shown in Table VI. The majority of isolations were made by the fifth day. Strains from infants frequently haemadsorbed on the third day, whereas strains from adults took much longer and were isolated with difficulty. Hence evidence of infection in adults was mainly serological.

TABLE VI.-Recovery of Parainfluenza Viruses from Pharyngeal Specimens. Time Required for Detection of Haemadsorption in Monkeykidney-tissue Culture

\begin{tabular}{|c|c|c|c|c|c|}
\hline \multirow{2}{*}{ Virus } & & \multirow{2}{*}{$\begin{array}{c}\text { Total } \\
\text { Isolations }\end{array}$} & \multicolumn{3}{|c|}{ Interval Required for Isolation (Days) } \\
\hline & & & 3 & 5 & 10 \\
\hline $\begin{array}{l}\text { Parainfluenza } 1 \\
\text { Parainfluenza } 2 \\
\text { Parainfluenza } 3\end{array}$ & $\begin{array}{l}\cdots \\
\cdots \\
\cdots\end{array}$ & $\begin{array}{r}21 \\
2 \\
2\end{array}$ & $\begin{array}{l}5 \\
0 \\
0\end{array}$ & $\begin{array}{r}14 \\
1 \\
1\end{array}$ & $\begin{array}{l}2 \\
1 \\
1\end{array}$ \\
\hline Total & $\ldots$ & 25 & 5 & 16 & 4 \\
\hline
\end{tabular}

Serology.-Table VII compares the results of C.F. and H.I. tests. The C.F. test appeared the more reliable, but the maximum number of significant increases in antibody titre were observed when both techniques were employed. Heterotypic rises to parainfluenza 1 and 3 viruses occurred frequently, making it difficult to be certain in the absence of isolation which virus was responsible. Table VIII shows the associated rises in antibody titre to Sendai virus. These occurred frequently in infections in which there was a rise to parainfluenza 1 virus or a rise to parainfluenza 1 and 3 viruses together. There was no rise in titre to Sendai virus occurring

TABLE VII.-Antibody Response to Parainfluenza 1, 2, and 3, as Measured by Complement-fixation and Haemagglutination-inhibition Tests

\begin{tabular}{|c|c|c|c|c|}
\hline \multirow{2}{*}{$\begin{array}{l}\text { Significant Rise } \\
\text { in Antibody }\end{array}$} & \multirow{2}{*}{$\begin{array}{l}\text { No. of } \\
\text { Patients }\end{array}$} & \multicolumn{3}{|c|}{ Positive Serological Tests } \\
\hline & & $\begin{array}{l}\text { Both } \\
\text { Tests }\end{array}$ & $\begin{array}{l}\text { H.I. } \\
\text { Only }\end{array}$ & $\begin{array}{l}\text { C.F. } \\
\text { Only }\end{array}$ \\
\hline $\begin{array}{ll}\text { Parainfluenza } 1 & \ldots \\
\text { Parainfluenza } 2 & \ldots \\
\text { Parainfluenza } 3 \\
\text { Parainfluenza } 1 \text { and } 3 .\end{array}$ & $\begin{array}{l}7^{*} \\
0 \\
3 \\
4^{*}\end{array}$ & $\begin{array}{l}5 \\
0 \\
1 \\
1\end{array}$ & $\begin{array}{l}1 \\
0 \\
0 \\
1\end{array}$ & $\begin{array}{l}1 \\
0 \\
2 \\
2\end{array}$ \\
\hline Total & 14 & 7 & 2 & 5 \\
\hline
\end{tabular}

* Parainfluenza 1 isolated from one of these cases. with homotypic responses to parainfluenza 3 virus alone. It was unlikely that other viral agents were responsible for illness in patients with serological evidence of parainfluenza infection, because paired sera failed to show any significant rise in titre to influenza A, B, C, adenovirus, respiratory syncytial virus, psittacosis, or $Q$ fever antigens, and apart from parainfluenza viruses no other viruses were isolated from these patients.

TABLE VIII.-Development of Antibody for Sendai Virus in Relation to Antibody to Parainfluenza 1, 2, and 3 Viruses

\begin{tabular}{|c|c|c|c|c|}
\hline \multirow{2}{*}{$\begin{array}{l}\text { Significant Rise } \\
\text { in Antibody }\end{array}$} & \multirow{2}{*}{$\begin{array}{l}\text { No. of } \\
\text { Patients }\end{array}$} & \multirow{2}{*}{$\begin{array}{c}\text { Significant } \\
\begin{array}{c}\text { Both } \\
\text { Tests }\end{array}\end{array}$} & \multirow{2}{*}{$\frac{\text { Rise in Sendai }}{\left|\begin{array}{c}\text { H.I. Test } \\
\text { Only }\end{array}\right|}$} & \multirow{2}{*}{$\begin{array}{l}\text { Antibody } \\
\text { C.F. Test } \\
\text { Only }\end{array}$} \\
\hline & & & & \\
\hline $\begin{array}{l}\text { Parainfluenza } 1 \\
\text { Parainfluenza } 2 \\
\text { Parainfluenza } 3 \\
\text { Parainfluenza } 1 \text { and } 3 \text {. }\end{array}$ & $\begin{array}{l}7 \\
0 \\
3 \\
4\end{array}$ & $\begin{array}{l}1 \\
0 \\
0 \\
1\end{array}$ & $\begin{array}{l}0 \\
0 \\
0 \\
0\end{array}$ & $\begin{array}{l}4 \\
0 \\
0 \\
1\end{array}$ \\
\hline Total & 14 & 2 & 0 & 5 \\
\hline
\end{tabular}

\section{Discussion}

Absolute proof that an illness is caused by a particular virus is not easy to obtain, particularly in general practice, where the collection of paired sera from children is undesirable. However, the clinical picture presented in those children from whom a parainfluenza virus was isolated was similar to that described by other investigators who have shown that the parainfluenza viruses are an important cause of acute respiratory infection, being particularly associated with the croup syndrome (Chanock et al., 1959 ; Kapikian et al., 1960 ; McLean et al., 1961 ; van der Veen and Smeur, 1961 ; Parrott et al., 1962). Furthermore, in some instances serological evidence of infection was obtained from adult secondary cases of acute respiratory infection within the same family. However, most surveys have involved somewhat artificial communities. This survey demonstrated that parainfluenza viruses play an important part in the aetiology of acute respiratory infection as seen by the general practitioner at home. During the time that the parainfluenza viruses were prevalent, 28 children with croup of varying severity were seen, and parainfluenza viruses were isolated in $21(75 \%)$ instances. It is possible that had serological specimens been obtained from children more cases would have been detected. The clinical picture varied from the typically mild illness in older children to the more severe forms of croup in infants and younger children. This suggests that the milder forms of croup often nursed at home are caused by the same viruses as the more serious infections that have been extensively studied in hospital.

Reports of infection in adults have been mainly in volunteers and military personnel, and have shown that the illness produced was mostly of a mild and afebrile nature (Tyrrell et al., 1959 ; Bloom et al., 1961 ; Dick et al., 1961). However, there have been occasional reports of febrile and more prolonged illness: McKinney et al. (1959) described two cases of an influenzalike illness in military personnel due to parainfluenza 3, while Evans and Brobst (1961) showed that parainfluenza viruses were responsible for $3.8 \%$ of lower respiratory infection in Wisconsin students. In Cambridge most of the illness that occurred in adults secondary to infection introduced by children was mild. In contrast, however, it was observed that there were no children in all but one of the families in which adults had a parainfluenza infection resembling influenza, and that this type of infection occurred mostly in older patients (mean age 45 years). It has been shown that reinfection with parainfluenza viruses is common and that the presence of neutralizing antibody modifies the severity of the infection (Chanock et al., 1961). Although the serologically confirmed cases had low resting levels of antibody to parainfluenza viruses by H.I. it is possible that the absence of children in the families prevented frequent encounters with these viruses and that the more prolonged and, by comparison, severe illness was the result 
of infection with parainfluenza viruses after a long lapse of time. Studies over a lengthy period in Washington, D.C. (Parrott et al., 1962), have revealed that parainfluenza viruses were prevalent throughout the year. Our study agrees with Ferris (1960) and Higgins et al. (1963) in finding a seasonal distribution of parainfluenza infection.

In Cambridge only febrile respiratory infection severe enough to require medical attention was investigated, and thus it was not possible to ascertain how much milder illness was due to parainfluenza viruses. Our survey has been carried out over a limited period of time and it is not certain that in other places similar findings will occur; only prolonged and continuous observations of this kind can provide such information.

\section{Summary}

A survey conducted from September 1962 to August 1963 in two general practices in Cambridge showed that parainfluenza viruses were responsible for $18 \%$ of all acute respiratory infections investigated. There was evidence of parainfluenza virus infection in 35 patients, most infections being due to parainfluenza 1 , but a few cases of parainfluenza 2 and 3 infection also occurred.

Croup was the commonest clinical manifestation in children. Infants and young children presented with the more severe illness, some degree of laryngeal obstruction frequently occurring. The older children presented with a milder illness, cough and hoarse voice often being found. There were 11 cases of parainfluenza infection in adults, most of whom presented clinically with an influenza-like illness.

The majority of cases occurred from September 1962 to January 1963. Studies of family episodes revealed that the highest secondary attack rate occurred in the youngest agegroups, and that the serial interval between cases was in the order of five days.

Viruses were isolated more easily from children than from adults, evidence of adult infection therefore being mainly sero- logical. The complement-fixation test was more efficient than the haemagglutination inhibition test in detecting significant rise in antibody titre to the parainfluenza viruses, but the best results were obtained when both tests were employed.

We are indebted to a number of persons for their contributions to this study: Dr. A. P. Waterson for his help throughout the preparation of this paper; Dr. R. B. Heath for doing the H.I. tests ; to Mrs. I. Nitkin for technical assistance, and Dr. C. M. Bradstreet, of the Central Public Health Laboratory, Colindale, for supplying serological reagents. We thank the Polio Research Fund for their generous contribution, which made it possible for this survey to be carried out.

\section{REFERENCES}

Andrewes, C. H., Bang, F. B., Chanock, R. M., and Zhdanov, V. M. (1959). Virology, 8, 129.

Bloom, H. H., Johnson, K. M., Jacobsen, R., and Chanock, R. M. (1961). Amer. 7. Hyg., 74, 50.

Bradstreet, C. M. P., and Taylor, C. E. D. (1962). Mth. Bull. Minist. Hlth Lab. Serv., 21, 96.

Chanock, R. M. (1956). F. exp. Med., 104, 555.

- Bell, J. A., and Parrott, R. H. (1961). In Perspectives in Virology, edited by $M$. Pollard, 2, 126. Chapman and Hall, London.

Vargosko, A., Luckey, A., Cook, M. K., Kapikian, A. Z., Reichelderfer, T., and Parrott, R.'H. (1959). \%. Amer. med. Ass., 169, 548.

Dick, E. C., Mogabgab, W. J., and Holmes, B. (1961). Amer. F. Hyg. 73, 263 .

Evans, A. S., and Brobst, M. (1961). New Engl. F. Med., 265, 401.

Ferris, A. A. (1960). Med. 7. Aust., 2, 768.

Heath, R. B., Tyrrell, D. A. J., and Peto, S. (1962). Brit. F. exp. Path. 43,444 .

Higgins, P. G., Ellis, E. M., and Boston, D. G. (1963). Mth. Bull. Minist. Hlth Lab. Serv., 22, 71 .

Kapikian, A. Z., Chanock, R. M., Bell, J. A., Reichelderfer, T. E., and Huebner, R. J. (1960). Pediatrics, 26, 243.

McKinney, R. W., England, B. L., and Froede, S. (1959). Amer. F. Hyg., 70, 280 .

McLean, D. M., Roy, T. E., O'Brien, M. J., Wyllie, J. C., and McQueen, E. J. (1961). Canad. med. Ass. F., 85, 290.

Parrott, R. H., Vargosko, A. J., Kim, H. W., Bell, J. A., and Chanock, R. M. (1962). Amer. F. publ. Hlth., 52, 907. Tyrreli, D. A. J., Bynoe, M. L., Petersen, K. B., Sutton, R. N. P., and
Pereira, M. S. (1959). Brit. med. F., 2, 909 .

van der Veen, J., and Smeur, F. A. A. M. (1961). Amer. F. Hyg., 74, 326.

Vogel, J., and Shelokov, A. (1957). Science, 126, 358.

Woodall, J., Rowson, K. E. K., and McDomald, J. C. (1958). Brit. med. f., 2,1316 .
The inoculation of human adult volunteers with an $M$ rhinovirus, H.G.P., was reported by Bynoe et al. (1961). They showed that some volunteers developed colds and that most of these had low levels of serum antibody or no antibody before inoculation. On the other hand, many of the volunteers who did not develop colds had high levels of antibody before inoculation; in other words, antibody had a protective effect. Similar results (Tyrrell, 1963) were obtained with another M rhinovirus, B632. M rhinoviruses grow in monkey-kidney cells in addition to human embryonic tissue and human malignant cells. Those rhinoviruses that grow only in human embryonic tissues and human malignant cells are termed " $H$ viruses." They have been isolated more frequently than $M$ viruses from subjects with colds (Tyrrell and Bynoe, 1961 ; Hamre and Procknow, 1961 ; Hamparian et al., 1961 ; Johnson et al., 1962 ; Kendall et al., 1962), and the antibody response of children and adults to primary infection with $\mathrm{H}$ viruses is poorer than the * From the W.H.O. International Reference Centre for Respiratory Virus Diseases and the M.R.C. Common Cold Research Unit, Salisbury, Wilts. response to $M$ viruses (Taylor-Robinson et al., 1963). Tyrrell and Bynoe (1961) demonstrated that some $\mathrm{H}$ rhinoviruses produced colds in volunteers, but they did not study the development of serum neutralizing antibody. Taylor-Robinson and Tyrrell (1962a) found that four of these $\mathrm{H}$ viruses were serologically distinct.

In the present experiments, viruses belonging to three of these serotypes have been inoculated intranasally into volunteers. Virus re-isolation in different human embryonic cells has been studied and serum neutralizing antibodies have been measured before and after volunteer inoculation in order to determine whether antibody prevents infection and/or colds.

\section{Materials and Methods}

Viruses.-The following three $\mathrm{H}$ serotypes were used: Sal./1/58H (F.E.B.), Sheffield/1/60H (16/60), and Sal./1/59H (Th.). A strain (T.) of the F.E.B. serotype and a strain (P.) of 